\title{
TELECOLLABORATION: FOSTERING FOREIGN LANGUAGE LEARNING AT A DISTANCE
}

\author{
AyseTaskiran[aysetaskiran@anadolu.edu.tr],Anadolu University,Turkey
}

\begin{abstract}
Today, language learners can be linked with students in other countries to form international partnerships, which is often called telecollaboration. Some common goals of telecollaboration include cultural awareness, development of foreign language skills and intercultural communicative competence. This study intends to gain insights about the learners' experience following a 5-week telecollaboration activity between 100 English as a foreign language (EFL) students from Jiangxi University of Finance and Economics in China and Anadolu University in Turkey. The participation in the project was on voluntary basis for Turkish students. The telecollaboration activity included three different stages in which learners from both countries were expected to be able to communicate using different channels (text messaging, voice calls, video calls, emailing) synchronously and asynchronously, to analyse and compare their own and their peers' culture to build understanding of each other's identities and to collaborate together to produce a cultural piece of work. At the end of the activity Turkish EFL students were invited to answer a questionnaire that aimed to gain insights about their experience related to telecollaboration activity. Results revealed that the participants mostly enjoyed the activity. They also believed the activity contributed to their language learning process, motivation and intercultural communicative competence.
\end{abstract}

\section{Abstract in Turkish}

Günümüzde, yabancı dil öğrenenler, genellikle teleişbirliği olarak adlandırılan etkinliklerle uluslararası ortaklıklar oluşturmak için diğer ülkelerdeki öğrencilerle çevrimiçi iletişim kurabilmekte. Teleişbirliğinin bazı ortak hedefleri arasında kültürel farkındalık, yabancı dil becerilerinin gelişimi ve kültürlerarası iletişimsel yeterlilik bulunmaktadır. Bu çalışma, Çin'deki Jiangxi Finans ve Ekonomi Üniversitesi'nden ve Türkiye'deki Anadolu Üniversitesi'nden İngilizce'yi yabanc1 dil olarak 100 öğrencinin katılımıyla gerçekleştirilen 5 haftalık bir teleişbirliği faaliyetinin ardından öğrencilerin deneyimleri hakkında bilgi edinmeyi amaçlamaktadır. Projeye katılım Türk öğrenciler için gönüllü olarak gerçekleştirilmiştir. Tele-işbirliği etkinliği, iki ülkeden gelen öğrencilerin, kendi ve akranlarının kültürünü analiz etmek ve karşılaştırmak için farklı kanalları (metin mesajlaşma, sesli aramalar, görüntülü aramalar, e-posta gönderme) kullanarak senkronize ve asenkron bir şekilde iletişim kurabilmelerinin beklendiği birbirlerinin kimliklerini anlama ve ortak kültürel bir eser üretmek için birlikte çalışmayı içeren üç farklı aşamayı içermiştir. Etkinliğin sonunda, Türk yabancı dil öğrencilerinin, teleişbirliği etkinliğiyle ilgili deneyimleri hakkında bilgi edinmeyi amaçlayan bir anket katılımcılara sunulmuştur. Sonuçlar, katılımcıların çoğunlukla etkinlikten keyif aldığını ortaya koymuştur. Ayrıca, bulgular katılımcıların etkinliğin dil öğrenme süreçlerine, motivasyonlarına ve kültürlerarası iletişimsel yeterliliklerine katkıda bulunduğu yönünde alg1larını ortaya koymuştur.

Keywords: Telecollaboration, EFL, Intercultural communicative competence. 


\section{Introduction}

Open and distance learning has evolved through different eras of educational, social, and psychological development (Anderson \& Dron, 2011; p.80), which most likely due to the advance of technological developments, particularly information communication technologies that have reshaped teaching and learning with a revolutional features provided by the internet technologies. Especially social-constructivist pedagogy, which founds on the personal construction of knowledge through social interaction (Bruner, 1990; Dewey, 1933; 1998; Piaget, 1970; Vygotsky, 1978) has drawn attention as an approach that emphasizes the collaborative nature of learning, the importance of the social context, the integration of learners into the information communities and their inclusion in collaborative processes. Jonassen (1994) summarizes some characteristics of constructivist learning environments as follows:

- authentic tasks in a meaningful context;

- real-world settings or case-based learning;

- environments that encourage reflective thinking;

- environments that enhance collaborative construction of knowledge through social negotiation.

Today, the information and communication technologies (ICT) enable all these characteristics to be implemented in teaching learning context in various practices. Learning environments are not limited to classroom anymore as they have become time and place independent. Recent foreign language teaching and learning practices are not exceptions. Although learning English as a foreign language (EFL) is often regarded as a challenge both for the teacher and the learner side due to limited real-life context to practice and foster the target language skills, with the advance of online communication tools it is not confined to the classrooms any more. Especially ubiquitous mobile technologies have made it possible to access educational resources from almost any place and practice language at any time. Therefore, online communication tools, particularly mobile devices, have been used eagerly in foreign language learning context. Thanks to some network-based communication tools, language learning has expanded beyond the classroom and it has gained an international dimension. By means of this flexibility, language teachers also get the advantage of cooperating with their colleagues from other countries. It is now possible for language learners to be linked with students in other countries to form international partnerships, which is often called telecollaboration. Studies on using web-based technologies in language learning seem to have promising results in terms of proving learners with a chance to interact across geographic, linguistic and cultural lines (Ware \& Kramsch, 2005). With these technologies communication across cultures becomes possible. This also helps extend communication, learning and teaching beyond the classroom.

\section{Literature Review}

\section{Telecollaboration}

Telecollaboration can be defined as the use of online communication tools to bring together language learners in different countries for the development of collaborative project work and intercultural exchange (O'Dowd \& Ritter, 2006). It is one of the common ways of benefitting from online communication tools. Among goals of telecollaboration are development of intercultural communicative competence (ICC) proposed by Byram (1997), development of foreign language skills and competences, and inclusion of new online literacies (Helm \& Guth, 2010; p.69). Despite the fact that ICC has gained importance in language learning contexts, not all learners have opportunities to practice language with other learners from diverse cultures (Çiftçi \& Savaş, 2018; p.1). Telecollaboration might be a promising way of fostering foreign language development encouraging learners to engage in collaborative, authentic, meaningful, 
and real-life based activities. Recent technologies have made it possible to interact globally, which in return created a requirement of certain skills, such as ICC, for language learners to be able to engage in global communication networks effectively. Upon gaining these skills, language learners can practice language with their peers from many different cultures all around the world. Researchers point out that ICT enhanced language learning contexts facilitate significant changes in the culturally dependent scenarios of language classroom compared to traditional foreign language classes (Belz, 2002; Hatch, 1992). Learners from diverse cultures can engage in linguistic and cultural exchanges with telecollaboration activities by collaboratively engaging in a series of tasks for developing foreign language competence and intercultural awareness. McCloskey (2012; p.44) pointed out that telecollaboration activities might provide the learners with opportunities to practice and improve their language skills through discovery and interaction. The author emphasized technological resources, metacognitive and reflection processes, and the expectations of students and teachers involved in the exchange as the most important aspects to be considered while planning such activities.

\section{Research on Language Learning}

Empirical studies focusing on foreign language teaching and learning at a distance covers various topics such as types of conferencing, issues of assessment and task design. Based on the number of studies, a blended mode of delivery and telecollaboration ranks second (Vorobel \& Kim, 2012; p.551). The research on telecollaboration for language learning has mixed findings; some claim success while some claim many challenges. It is claimed that telecollaboration might have promising results such as personal benefits, cultural benefits, linguistic, and sociolinguistic advances (Helm \& Guth, 2010; pp.109-110). Some pedagogical benefits include promoting learner autonomy, fostering language awareness and fluency, developing intercultural communicative competence and facilitating learner's critical reflection on their own culture. Telecollaboration helps those hesitant students to step out of their world and use the target language outside the classroom. Experiences of international communication stimulates learners' curiosity and motivation as in projects indicating positive influence on students who are motivated by the opportunity of communicating with non-native speakers (Michell, 2011).

Similarly, some research points out that it fosters communication skills development and it raises critical cultural awareness. On the teacher's side, telecollaboration seem to promote professional development (Helm \& Guth, 2010; pp.109-110). In a study by Gómez (2019) the prospective English teachers of Colombia took part in telecollaboration activities with their US counterparts and thanks to this activity, prospective teachers developed more positive opinions about themselves, confronted the harmful effects of native speaker ideologies and could eliminate those negative effects.

Over the last few decades some research has focused on language forms in online interactions. The studies focused on how often learners tend to use newly learned language structures during their online conversations, how they notice, process and discuss some language forms and how they negotiate over some functions in telecollaborative partnerships (Belz, 2002; Levy \& Kennedy, 2004). Ware and O'Dowd (2008) focused on peer feedback strategies on language forms and they found out that even though the learners appreciated getting feedback from their online partners, their integration of feedback into online interactions was limited unless given explicit directions by their instructors.

In the field of foreign language learning in higher education, telecollaboration has been examined most frequently from sociocultural perspectives and it promises to have the potential to enrich the learning experience by providing learners with opportunities for interaction and communication with others who are practicing the same language. Therefore, telecollaboration studies also focused on cultural aspects and ICC. It is known that linguistic competence by itself 
does not guarantee successful communication with learners from various cultural backgrounds (Schenker, 2012). According to Byram (1997) language learners need more than grammatical skills and knowledge for better communication. They should be able to know how and when to use specific language appropriately, which includes pragmatic competence, discourse competence and communicative competence as well. Learning a foreign language is connected to intercultural aspects, as language and culture are perceived to be two sides of the same coin (Belz, 2002; Thorne, 2006; Ware \& Kramsch, 2005). Consequently some studies focused on the development of ICC (Byram, 1997; Chun, 2011) and some others focused on conflicts that occurred in online conversations (O’Dowd \& Ritter, 2006; Ware \& Kramsch, 2005).

Telecollaboration in language learning does not always result in success and some practices resulted in difficulties, tension and failure. O'Dwod and Ritter (2006) reviewed the existing body of research in order to develop a structured inventory of reasons behind failed communications in online exchanges and they grouped the interconnected factors into four levels; individual, classroom, socio-institutional and interaction. In order to find an answer why telecollaboration projects sometimes fail, Harris (2000) pointed out some factors including not enough technical, administrative, financial support, inauthentic project, too complex planning. Belz (2002) emphasizes the complexity of telecollaboration studies by pointing out that:

"the social action of telecollaborative foreign language study is a complex and multifaceted buman activity. This activity is shaped by an intricate inter-relationship of social and institutional affordances and constraints, aspects of individual psycho-biography, as well as language and computer socialization experiences and particular power relationships." (p.73)

This study intended to gain insights about learner experience form learners' perspective. Their novel ideas, evaluations and suggestions might shed light on the potential benefits of telecollaboration in EFL context, as well as bringing out some solutions for the drawbacks that might occur in similar future practices.

\section{Methodology}

\section{Background Information}

This three-phase study included a five-week telecollaboration activity between Chinese and Turkish EFL learners in higher education context. The researcher, who is an EFL instructor, met the Chinese EFL instructor who was looking for a partner school for a telecollaboration activity on Edmodo, which is a social network created for educational purposes. Providing educators, researchers and learners with a free and secure learning space, Edmodo brings advantages of collaboration, communication, assistance, practice, shareable course materials, and group discussions. Both instructors were teaching to lower intermediate level students who took placement tests at the beginning of the semester at their own higher education institution, and the instructors decided to start a tele-collaboration activity together. Participation in the project was on voluntary basis for Turkish students but for Chinese learners, it was an assignment that would be a part of their assessment. Chinese participants were studying at Jiangxi University of Finance and Economics in China and Turkish students were studying at School of Foreign Languages in Anadolu University in Turkey. Turkish EFL learners were attending in an intensive language program at preparatory class and they were of various departments. Participation to the activity was on voluntary basis and 53 Turkish students wanted to join the activity. As the number of the participants from each country was not equal, some students formed groups of 3 instead of pairing up. 


\section{Research Questions}

The following questions guided this study:

- Do Turkish EFL learners believe that the telecollaboration activity contributed to their language learning process?

- Do Turkish EFL learners believe that the telecollaboration activity increased their motivation for learning English?

- Do Turkish EFL learners believe that the telecollaboration activity contributed their intercultural communicative competence?

\section{Stages and Procedures}

The telecollaboration activity included three stages: information exchange stage, comparison and analysis stage and collaboration and product creation stage. Before the instructors informed the learners about the activity, they decided on a communication channel. A mobile application, WeChat, was chosen as a practical mobile conversation channel. The instructors practiced on the application in order to discover and practice its functions. The application was quite handy as it supported videoconferencing, and sharing text messages, photos and videos. The instructors planned the activity in a timeline in detail. Throughout all stages of the activity the participants were free to choose any communication mode they preferred such as sending text messages, photos, voice recordings, video or text files and making video conferences or voice chats. In the information exchange stage, the instructors from both countries paired up the students and asked them to get to know each other for a week. The participants gathered information about their daily lives as university students, their departments, likes and dislikes and hobbies using the target language. In the comparison and analysis stage, the learners discussed a common topic food in their culture. They asked and answered each other's food culture, cuisine, eating habits, favourite recipes, preferred food choices and also the food they do not like. During this stage the participants were supposed to share as many videos or photos as possible. In the final stage the participants were supposed to work together to create a product. At this stage the participants were provided with choices such as shooting a video on a recipe, presenting a specific food peculiar to that culture, or preparing a presentation about a food festival or typical food types for different celebrations. At the end of the product creation stage Turkish participants gave their presentations in the classroom, while Chinese participants shot videos of their presentations shared them with the Turkish instructor on the Internet. As participation was on voluntary basis for Turkish students, they were not graded on their presentations, but Chinese participants were graded on their performances.

\section{Data Collection and Analysis}

The researcher compiled a questionnaire including 16 items with a 5-point scale that offered a range of answer options from strongly disagree to strongly agree. The items aimed to get information about the effect of telecollaboration on development of foreign language skills (6 items), language learning motivation (5 items) and development of ICC (5 items). At the end of the questionnaire the participants were allowed to state their suggestions related to the activity. The questionnaire was sent to the participants as an electronic form and frequency statistics were calculated.

\section{Results}

The questionnaire consisted of 16 items, 6 of which aimed to get information regarding to what extent telecollaboration activity contributes to foreign language skills. Figure 1 displays the percentages of the strongly agree answers for the above mentioned items. For almost all language skills and areas, the participants found the activity quite beneficial. Results indicate that participants found writing and reading skills together with vocabulary knowledge to be improved 
by telecollaboration activity more than the other language skills and areas. For writing and reading skills $95.7 \%$ of the participants responded choosing strongly agree and agree for the statements "This activity contributed to my English writing skill" and "This activity contributed to my English reading skill". Similarly, $91.5 \%$ of the participants chose strongly agree and agree for the statement "This activity contributed to my English vocabulary knowledge". Also, 74.9\% of the participants responded choosing strongly agree and agree for the statement "This activity contributed to my English speaking skill". The least scored item was related to listening skill as strongly agree and agree responses added up to $61.2 \%$, which was followed by grammar knowledge with $70.9 \%$.

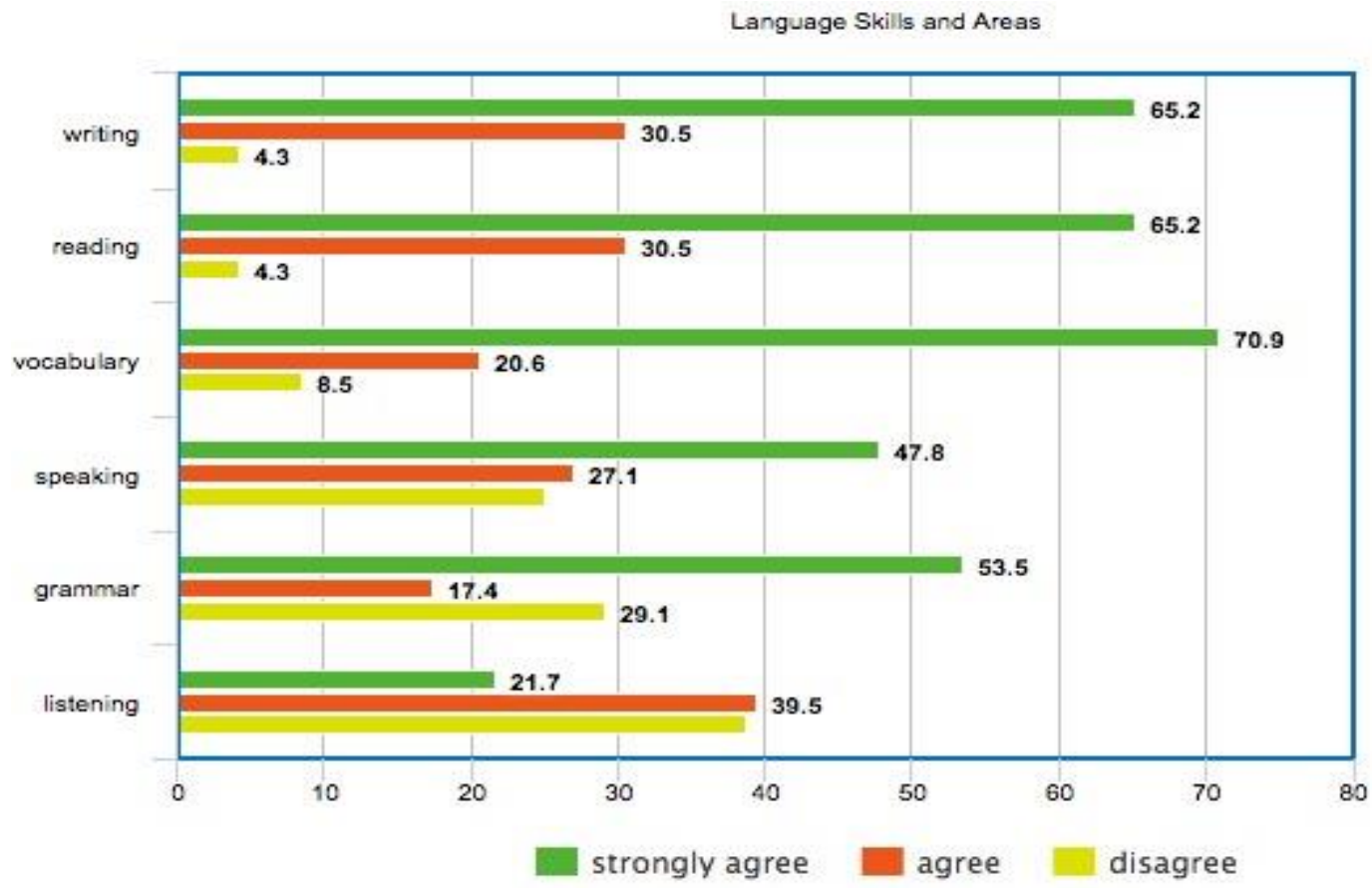

Figure 1. Items related to the effect of telecollaboration on language skills

With regard to language learning motivation the questionnaire included 5 statements. The percentages for strongly agree, agree and disagree responses for each statement can be seen in Figure 2. Results indicate that the activity was found to be quite motivating. The highest percentages were for the statements regarding the effect of telecollaboration activity on motivation in general for English language learning, developing positive attitude towards English language, and becoming aware of one's English language competence each with $95.7 \%$. They were followed by the statements "enjoy practicing English" with 95.6\% and "keep practicing English outside the class" with $91.4 \%$. 


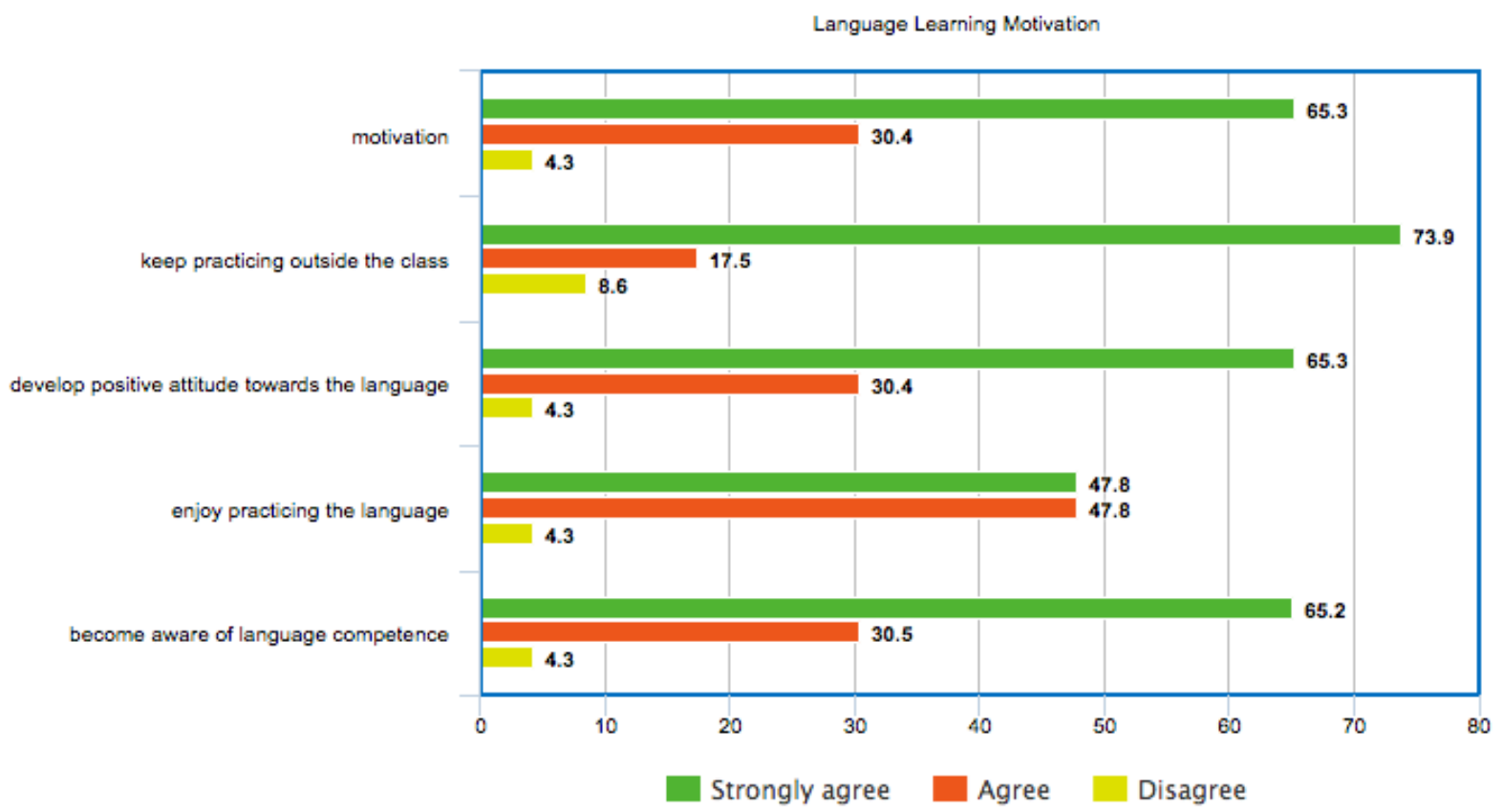

Figure 2. Items related to language learning motivation

The number of the statements regarding the ICC was 5. All statements were responded as strongly agree and agree with high percentages. The statements: "become more willing to communicate with people from other cultures" and "become confident about interacting with other people" were the top scoring ones with $95.7 \%$, which were followed by the statements "cultural differences improve my communication skills" with $95.6 \%$ and "I could develop cultural competence thanks to this activity" and "I could become aware of cultural differences thanks to this activity" with $91.4 \%$ both.

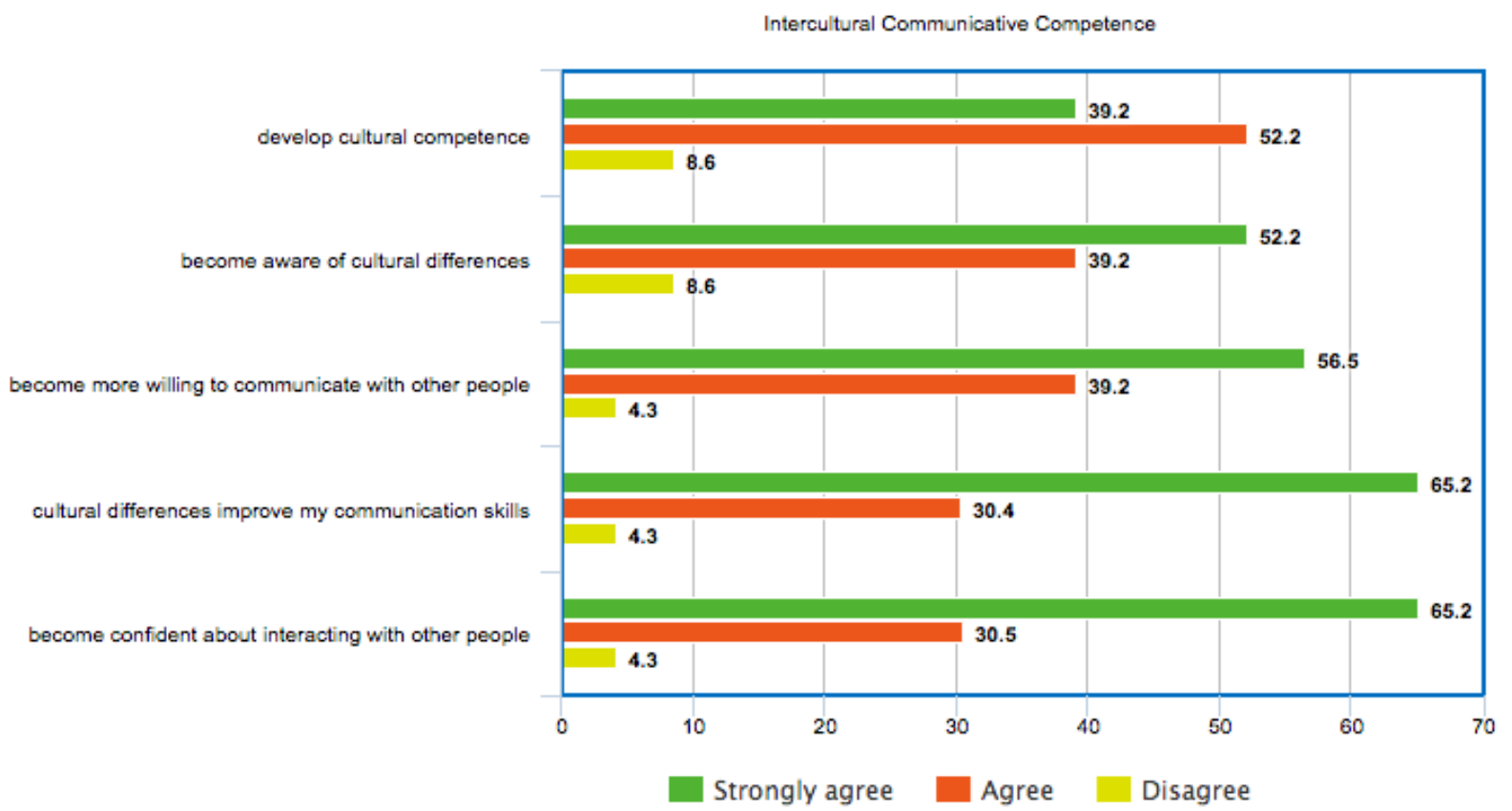

Figure 3. Items related to telecollaboration and ICC

At the end of the questionnaire the participants were asked to make any suggestions or comments related to the telecollaboration activity they took part in. Below are some quotes from those students who responded the final section. 
"I have benefitted greatly from the telecollaboration activity. It helped me improve my language skills. Only problem was the buge time differences between the countries."

"WeChat is a great application! We shared photos and videos of our daily lives. It was great to use a mobile app so we could even chat while we were on the bus or outside."

"At first I did not have the courage to chat with someone in English but in time I realized that it was not that difficult. Our online partners were almost like us. We were not so different from each other. Their daily lives at university were quite similar to our lives."

"I made great friends thanks to this activity. My online friend is going to visit Turkey next year and I am really excited to host my friend here!"

"While chatting with my Chinese friend, I learned how to use some dictionary apps and I could use the structures or words we learned in class in my own sentences. It was really beneficial to practice words and structures in real life with real people."

"We had a big time difference between Turkey and China. When I was available for chat my Chinese friend was about to go to bed. However, we both tried to create time for each other by making sacrifices."

"Chatting with someone from another country was a great opportunity for me to improve my English. We had no other choice than English in order to communicate so we tried our best to practice English. My Chinese friend was also learning English as a foreign language so we learned from each other a lot."

\section{Conclusion}

This study took place in European and Asian contexts, which contributed to telecollaboration research, as one observable pattern in the literature was the dominance of interactions between Western country contexts (Çiftçi \& Savaş, 2018). The study was also significant because the participants were all EFL learners. Most telecollaboration studies include native speakers of each target language (Angelova \& Zhao, 2016; Chun, 2011; Gómez, 2019). This might have resulted in negative language transfers, yet it might have also contributed to higher motivation and participation rate, as the participants from both countries knew that they were all learning English as a foreign language so their mistakes were tolerable to both sides. Similar to the findings of many other studies in telecollaboration research (Angelova \& Zhao, 2016; Belz, 2006; Lee \& Markey, 2014; Ware \& O’Dowd, 2008) the results clearly indicated positive telecollaborative experiences with very small percentage of negative responses to the statements in the questionnaire. Participants favoured the activity with much greater percentages of strongly agree responses not only for the items related to language skills and areas, but also for the items related to language learning motivation and developing ICC.

Overall high scores for the items regarding the language skills and areas revealed the fact that telecollaboration offers a worthwhile opportunity to improve language skills and areas for foreign language learners, which is a similar finding with some studies (Angelova \& Zhao, 2016; Chen \& Yang, 2016; Guth \& Marini-Maio, 2010). For example, the study by Chen and Yang (2016) revealed that participants experienced a sense of achievement, and they believed the telecollaboration helped them improve self-scaffolding skills thanks to less stressful learning opportunities. The fact that reading and writing skills were the ones that received the highest scores might be because they mostly sent short text messages as a mode of communication during information exchange stage, and comparison and analysis stage of the activity. Also, in order to exchange information during these stages, learners tended to search for new vocabulary 
items, or they often checked out how to use words appropriately in their sentences, which might have led to higher scores for the statement regarding vocabulary development on the scale. Moreover, three-fourths of the students suggested that their speaking skills improved. One reason why speaking and listening skills did not receive as high scores as reading and writing may be the chosen application, WeChat, for the activity. As they communicated on a mobile chat application similar to WhatsApp, they tended to send short text messages rather than making voice or video conferencing. In another telecollaboration study in which Skype was selected as the medium of communication, the participants responded that Skype sessions helped them become more accurate in their speaking and helped them feel more secure when speaking in the target language (Guth \& Marini-Maio, 2010). From this perspective, it can be concluded that the communication platform chosen while planning such activities has an impact on the outputs. If the teachers expect to improve their learners' oral communication skills, they can prefer videoconferencing tools like Skype, Google Hangouts, or Facebook Live. On the other hand, if the aim is to improve writing skills through short messages, WeChat or WhatsApp might be more convenient.

It is obvious that motivating learners to practice a foreign language outside the classroom where it is almost impossible to create real contexts is a big challenge. The telecollaboration activity in this study seems to be promising for overcoming this challenge to a great extent. According to results, learners claim that they enjoyed practicing the language with their online partners outside the classroom. They state that the activity motivated them to use what they learn in the class in their daily lives in real conversations. By this way, the learners seemed to become more aware of their language competence and become more motivated to engage in language exchanges, which in return helped them develop greater confidence in their foreign language skills. Classroom lectures might have become more meaningful for the learners as they could transfer lesson content to their real life language exchanges.

Telecollaboration activities aim at not only improving language skills and motivation but also promoting ICC. By means of telecollaborative activities, learners find opportunities to grow interculturally (Liaw \& Bunn-Le Master, 2010). Similar to the findings of many other studies in the literature (Angelova \& Zhao, 2016; Chen \& Yang, 2016), the participants in this study claimed that they became more aware of other cultures. As mentioned in the comments made by the participants, the learners rejoiced at the similarities between Chinese and Turkish university students' daily lives. They claimed that at first it seemed to be a challenge to chat someone from another culture in English but later on they developed self-confidence and become more interested in each other's culture.

Telecollaboration activities might result in success as long as some points are considered seriously. First and foremost, a good teacher cooperation is essential. If teachers maintain good communication, then the project reaches success with better planning, coordination and teamteaching. This might also create a good role model for the learners. Another important point to be considered is planning up the activity to the finest detail. With the consensus of both sides every step should be placed in a time-table with detailed explanations. Also, the learner profiles such as language proficiency levels, ages, expectations should be similar to each other. Another significant point that affects success in telecollaboration is designing the task. This requires serious cooperation among the teachers. The teachers should spend plenty of time on designing the task by considering both sides' curricular requirements, learner profiles, learners' interests. Choosing the topics that draw learners' attention, that can be sequenced meaningfully and that foster the development of targeted language skills requires profound effort.

It can be concluded that telecollaboration activity revealed positive linguistic and sociocultural outcomes. These activities can be a good alternative to get EFL learners to put what they learn in 
the classroom into practice in their daily lives. As a part of mobile learning, similar chat applications seem to be appealing for language learners as they find them quite handy and familiar. Giving participants a questionnaire following the telecollaboration activity can be carried one step further by adding focused group interviews with the participants. That might provide researchers with more insights into learners' attitudes and reflections on the activity.

\section{References}

1. Anderson, T., \& Dron, J. (2011). Three generations of distance education pedagogy. The International Review of Research in Open and Distributed Learning, 12(3), 80-97.

2. Angelova, M., \& Zhao, Y. (2016). Using an online collaborative project between American and Chinese students to develop ESL teaching skills, cross-cultural awareness and language skills. Computer Assisted Language Learning, 29(1), 167-185.

3. Belz, J. A. (2002). Social dimensions of telecollaborative foreign language study. Language Learning \& Technology, 6(1), 60-81.

4. Belz, J. A. (2006). At the intersection of telecollaboration, learner corpus analysis, and L2 pragmatics: Considerations for language program direction. Internet-mediated intercultural foreign language education, 207-246.

5. Bruner, J. S. (1990). Acts of meaning (Vol. 3). Harvard University Press.

6. Byram, M. (1997). Teaching and Assessing Intercultural Communicative Competence. Clevedon, UK: Multilingual Matters.

7. Chen, J. J., \& Yang, S. C. (2016). Promoting cross-cultural understanding and language use in research-oriented internet-mediated intercultural exchange. Computer Assisted Language Learning, 29(2), 262-288.

8. Chun, D. M. (2011). Developing intercultural communicative competence through online exchanges. CALICO Journal, 28(2), 392.

9. Çiftçi, E. Y., \& Savaş, P. (2018). The role of telecollaboration in language and intercultural learning: A synthesis of studies published between 2010 and 2015. ReCALL, 30(3), 278-298.

10. Dewey, J. (1933). How we think: A restatement of the relation of reflective thinking to the educative process. DC Heath.

11. Dewey, J. (1998). Experience and education: The 60 $0^{\text {th }}$ anniversary edition. Kappa Delta Pi.

12. Gómez, M. V. G. (2019). Developing Soft Skills in Higher Education Foreign Language Programs. Initial Insights into Telecollaboration. In Teaching Language and Teaching Literature in Virtual Environments (pp. 151-162). Springer, Singapore.

13. Guth, S., \& Marini-Maio, N. (2010). Close encounters of a new kind: The use of Skype and Wiki in telecollaboration. Telecollaboration, 2, 413-426.

14. Harris, J. (2000). Taboo Topic No Longer: Why Telecollaborative Projects Sometimes Fail. Learning \& Leading with Technology, 27(5), 58.

15. Helm, F., \& Guth, S. (2010). The multifarious goals of telecollaboration 2.0: Theoretical and practical implications. In F. Helm \& S. Guth (Eds.), Telecollaboration 2.0: Language Literacies and Intercultural Learning in the $21^{\text {st }}$ Century (pp.69-106).

16. Jonassen, D. H. (1994). Thinking technology: Toward a constructivist design model. Educational Technology, 34(4), 34-37.

17. Lee, L., \& Markey, A. (2014). A study of learners' perceptions of online intercultural exchange through Web 2.0 technologies. ReCALL, 26(3), 281-297. 
18. Levy, M., \& Kennedy, C. (2004). A Task-Cycling Pedagogy Using Stimulated Reflection and Audio-Conferencing in Foreign Language Learning. Language Learning \& Technology, 8(2), 5068.

19. Liaw, M. L., \& Bunn-Le Master, S. (2010). Understanding telecollaboration through an analysis of intercultural discourse. Computer Assisted Language Learning, 23(1), 21-40.

20. McCloskey, E. M. (2012). Global teachers: A conceptual model for building teachers' intercultural competence Online [Docentes globales: un modelo conceptual para el desarrollo de la competencia intercultural on-line]. Comunicar, 38, 41-49.

21. Michell, H. (2011). A critical analysis of the effects of a videoconferencing project on pupils' learning about culture and language. Journal of Trainee Teacher Education Research, 2, 51-88.

22. O’Dowd, R., \& Ritter, M. (2006). Understanding and working with 'failed communication' in telecollaborative exchanges. CALICO Journal, 23(3), 623-642.

23. Piaget. J. (1970). Structuralism. New York: Basic Books.

24. Schenker, T. (2012). Intercultural competence and cultural learning through telecollaboration. CALICO Journal, 29(3), 449.

25. Thorne, S. L. (2006). Pedagogical and praxiological lessons from internet-mediated intercultural foreign language education research. Internet-mediated Intercultural Foreign Language Education, 2-30.

26. Vorobel, O., \& Kim, D. (2012). Language teaching at a distance: An overview of research. Calico Journal, 29(3), 548.

27. Vygotsky, L. S. (1978). Mind in society: The development of higher psychological process. London: Harvard University Press.

28. Ware, P. D., \& Kramsch, C. (2005). Toward an intercultural stance: Teaching German and English through telecollaboration. The Modern Language Journal, 89(2), 190-205.

29. Ware, P. D., \& O'Dowd, R. (2008). Peer feedback on language form in telecollaboration. Language Learning \& Technology, 12(1), 43-63. 